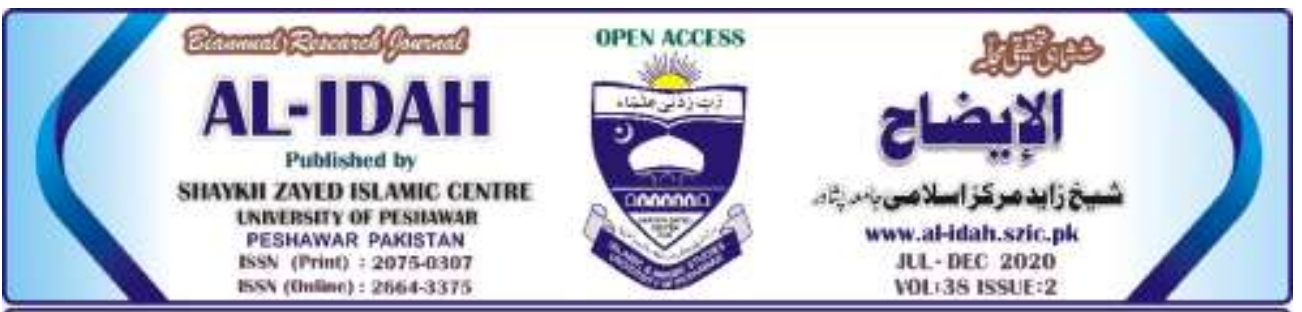

\title{
The Narrations of Sufyānaīn in Shahīh al-Bukhārī
}

Author(s): 1. Alam Khan

Assistant Professor, Department of Hadīth, Faculty of Theology, University of Gumushane-Turkey Email: alamiiu09@gumushane.edu.tr

Issue: http://al-idah.szic.pk/index.php/al-idah/index

URL:http://al-idah.szic.pk/index.php/al-idah/article/view/649

Citation: khan, A. 2020. The Narrations of Sufyānaīn in Shahīh al-Bukhārī. Al-Idah . 38, - 2 (Dec. 2020), 1 - 18

Publisher: Shaykh Zayed Islamic Centre, University of Peshawar, Al-Idah - Vol: 38 Issue: 2 / July-Dec 2020/ P.1-18

Article DOI: https://doi.org/10.37556/al-idah.038.02.649
Received on: 19-07-2020

Accepted on: 30-09-2020

Published on: 25 Dec 2020

\section{Ahstract}

Sahīh al-Bukhārī is considered one of the most authentic books in Hadith literature because Imām alBukhārī (d. 256/870) narrated ahādìth on the authority of a meticulous procedure and on the credit of the veritable and verifiable narrators. Sufyān alThawrī (d. 161/777) and Sufyān b. Uyaynah (d. 198/813) are topmost among the trustworthy and reliable narrators and are considered as mentors in Hadith and its sciences. Quite a sizable number of ahädith are quoted in Sahīh al-Bukhārī on their authority. As the students of Sufyān al-Thawrī and Ibn Uyaynah usually refer to them by their names which makes it easier to access their narrations. However, there are a number of narrations in Sahāh al-Bukhārī that are ascribed by the common name Sufyān with no clue whether these narrations belong to Sufyān al-Thawrī or Sufyān $b$. Uyaynah. A consensus developed from the historical position is that Sufyān al-Thawrī is the preceptor of Sufyān $b$. Uyaynah. Hence whenever there are two intermediaries among al-Bukhārī and Sufyān, it would be al-Thawri, and whenever there is one narrator between al-Bukhārī and Sufyān, it would be Ibn Uyaynah.

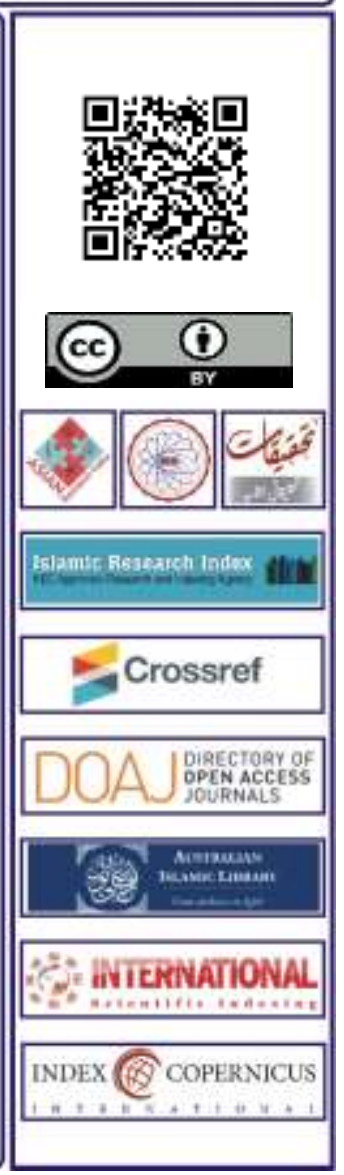


This study aims to focus on the five hundred and seventy-eight (578) ahādith in Sahīh al-Bukhārī that have been narrated on the authgority of fourteen (14) narrators from Sufyān al-Thawrī or Ibn Uyaynah. Moreover those narrators are referred to their source in sanad on Sufyān only. Consequently, the study is concluded on the way of differentiation between the narrations of both narrators and brings round the ahädīth belong to Sufyān al-Thawrī as well as the ahädīth belong to his student Ibn Uyaynah in Sahīh al-Bukhārī.

Keywords: Hadith, al-Bukhārī, Refer, Intermediary, Methodology.

\section{Introduction:}

The Prophetic ahādīth have been narrated in different ways until they got codified in the canonical books. The usual method was Oral-transmission in the early first century after Hijra. However, it does not portend that the early narrators did not write down the ahādīth because historically a plethora of written manuscripts belonging to the famous Muhaddithūn of the Prophet's companions, Tābi'ūn (successors), and their students. The codification and collection of hadith officially commenced at the end of the first century, Umar b. Abdil-Aziz (d. 101/720) instructed his governor Abū Bakr Muhammad b. Hazm (d. 120/738) for the amassment of Prophetic ahādīth. Moreover, Ibn Shihāb al-Zuhrī (d. 124/742) hailed this official order and collected ahādīth on a gamut. ${ }^{(1)}$

The third-century which is considered the golden period in the history of hadith collection- Muhaddithūn compiled valuable books in authentic ahādith and sorted them under various heads. They relied on the division of ahādīth on Islamic jurisprudence-Muhammad b. Ismāil al-Bukhārī (d. 256/870) was among those scholars who took apart in this project and compiled the Prophetic ahādīth with a comprehensive scrutiny of these compilations.

Al-Bukhārī is declared as the most authentic book after the Holy Qurān due to his meticulous methodology in the selection of narrations, he narrated ahādīth in the Aslu'l-bāb on authority of the reliable narrators of hadith who exercised utmost care and scrutiny before reporting any Hadith. Interestingly al-Bukhārī narrated hundreds of ahādīth from the two prominent Muhaddithūn of the second century called Sufyān alThawrī (d. 161/777) and Sufyān b. Uyaynah (d. 198/813), The Shuyūkh of al-Bukhārī conventionally refer to them in their Isnād on their full names or surnames to differentiate between the two. However, there are some ahādīth that are narrated through"Sufyān" only which created ambiguity that whether these are the narration of Sufyān al-Thawrī or the narrations of his student Sufyān Ibn Uyaynah. Both narrators are an authority but it seems worth investigating to explore any differences between them for differentiation in their narrations.

\section{Sufyān Al-Thawrī and Ibn Uyaynah:}

The biographical books mention that Sufyān b. Sa'īd b. Masrooq alThawrī was born in (97/716). He was one of the prominent scholars of alKūfa who travelled far and wide for learning ahādīth. He was settled in 
al-Küfa. However, later he left his native town due to the personal conflict with the Khalifa Mahdī and died in al-Basra in (161/777). ${ }^{(2)}$

Sufyān al-Thawrī received his early education at home from his father Sā̄d b. Masrūq (d. 128/746)- a junior Tābī and a well-known Muhadith. Later he joined the lessons given by Ayūb al-Sakhtiyān̄i, Bahz b. Hakim, Sulaymān al-A'mash, Shu'ba b. al-Hajjāj, Muhammad b. al-Munkadir, Mamar b. Rāshid, Hishām b. Urwa and other Muhaddithūn of his time. He was famous for hadith narration among his contemporaries. A considerable number of students listened to ahādīth from him. Ibn alJawzī (d. 597/1200) claimed that al-Thawrī has more than $(20,000)$ students. However, al-Dhahabī (d. 748/1347) called it preposterous and stated that their number marginally reached to (1000) students. He fortified his thesis that none of the hadith scholars narrated more than Mâlik (d. 179/795) while the number of his students did not exceed $(1,400)$ that include the unknown narrators. ${ }^{(3)}$

He was well aware of his sharp memory-Abdullāh b. al-Mubarak (d. 181/797) accoladed him that he wrote from (1,100) Muhaddith of his time, but none of them was better than Sufyān al-Thawrī. Likewise, Yūnus b. Ubayd who had met the genius scholars of his time such as Sa'̄̄d b. Jubaīr, Ibrāhīm al-Nakhaī, and Mujāhid uttered the same view about al-Thawrī that he had never seen a person better than him. Ibn Mahdī (d. 198/813) graded Mālik as a better scholar of his time but claimed that he was never more vigorous in hadith memorization than alThawrī. Moreover, his student, Sufyān b. Uyaynah believes that he was more knowledgeable in the subject of Halāl and Harām. ${ }^{(4)}$

\subsection{Sufyān b. Uyaynah:}

Abū Muhammad Sufyān b. Abi Imrān b. Uyaynah al-Kūfī was born in (107/725)-Kūfa. He got his early education in his home town and remained in company of the well-kenned Muhaddithūn of his era. He participated in the lectures of Amar b. Dinār and narrated from him profusely. He peregrinated for ahādīth to the famous centres of his time and listened to the prominent shuyūkh such as Ibn Shihāb al-Zuhrī, Muhammad b. al-Munkadir, Zaīd b. Aslam, Shu'ba b. al-Hajjāj, Sufyān al-Thawrī, and other immense numbers of scholars. ${ }^{(5)}$

Ibn Uyaynah was himself a reliable narrator and great Muhaddith to the extent that his teachers narrated ahādīth from him. As for instance, Shu'ba b. al-Hajjāj, who was his teacher and a hadith scrutinizer in Iraq had narrated many narrations from Ibn Uyaynah as well as al-A'mash and Ibn Juraij withal narrated from him. At the same time, both are listed in biographical lexicons of his teachers like Shu'ba. ${ }^{(6)}$

A research on his biography, the appreciative comments of his students and later scholars reveal that he was also an expert on hadith and an erudite in Halāl and Harām like his preceptor Sufyān al-Thawrī. Imām alShāfi'i (d. 204/820) stated that he found all of the ahādīth cognate to the provisions (al-Ahkām) of Sharia with Ibn Uyaynah except seven ahādīth. It shows his calibre of memorizing ahādīth that he listened from his 
contemporary Muhaddithūn. It is mentioned in his biographical sources that he travelled to Hijāz and died in (198/813) -Makkah. However, he quenched his thirst of knowledge from the prominent hadith scholars of Hijāz. He memorized their ahādīth as comprehended of al-Shāfi' $\overline{1}$ and Abdu'r-Rahmān al-Mahdī statement that he was the most cognizant hadith scholar of Hijāzi narrations and if he was not, the knowledge of Hijāz was lost. ${ }^{(7)}$

The exhaustive study of Ibn Uyaynah's biography revealed that he was a student of al-Thawrī, and he shared some shuyūkh with him such as Muhammad b. al-Munkadir, Sulaymān al-A 'mash, Abdullāh b. Shubrama (d. 144/760), Ismāil b. Abi Khālid (d. 146/762) and Shu'ba b. al-Hajjāj, as well as two students, such as Muhammad b. Yusuf al-Firyabī (d. 213/828) and Abū Nu'aim al-Fadl b. Dukayn (d. 219/834).

\section{Al-bukhārī and the narratıons of both scholars:}

A superficial review of the narrations of both scholars in Sahīh al-Bukhārī reveals that whenever Muhammad b. Ismāil al-Bukhārī narrated from Sufyān al-Thawrī, there are two narrators among them, but whenever narrating from Sufyān Ibn Uyaynah, there is one narrator among them. However, the profound study of the Sahīh al-Bukhārī reveals that it does not apply to every narration because in some narrations of al-Thawrī there is an intermediary of narrator. For instance, Khallād b. Yahyā (d. 213/828) was a well-kenned student of al-Thawrī, and al-Bukhārī narrated from him as given below:

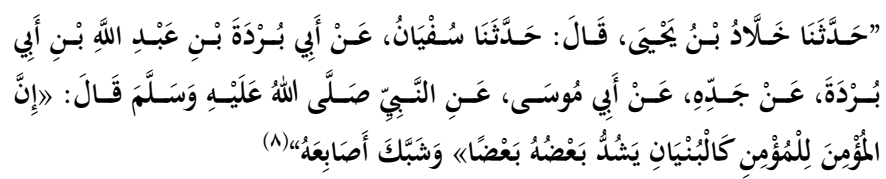

Consequently, it could not be made a general rule that whenever there are two narrators among al-Bukhārī and Sufyān, it would be al-Thawrī. Any exhaustive and comparative study of Sahīh al-Bukhārī may reveal that there are about five hundred and seventy-eight (579) ahādīth of fourteen (14) narrators that they refer to their Sheikh on "Sufyān" without identification. Their concise biographies and essential information about their narrations in Sahīh al-Bukhārī are as follow.

\subsection{Khallād Ibn Yahyā as-Sulamī:}

Abū Muhammad Khallād b. Yahyā b. Safwān as-Sulamī (d. 213/828) was born in al-Kūfa and spent his life in Makkah. He joined the sermons of the well-known Hijāzī and Kufī hadith scholars such as Ibrāhīm b. Nāfi al-Makkī, Ismāil b. Abdulmālik, Bashīr b. al-Muhājir and Sufyān alThawrī. (9) He was a reliable narrator, and al-Bukhārī narrated about seven (7) ahādīth on his authority that he solely referred in it to his source on Sufyān. Nevertheless, there is one hadith regarding what someone committed in the Jāhiliyyah that Sufyān narrated from al-A'mash, who is 
an ordinary Sheikh of al-Thawrī and Ibn Uyayna. The sanad goes as follows:

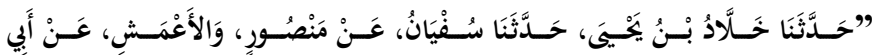

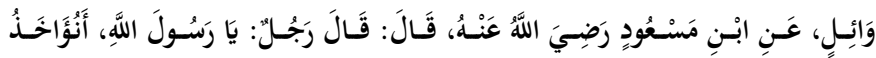

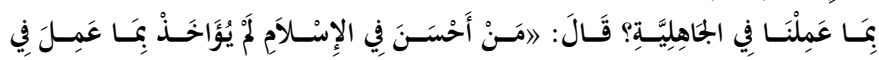

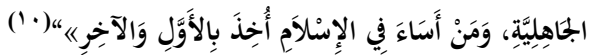

A cursory glance at the above sanad engenders the confusion that whether it is the narration of Sufyān al-Thawrī or Ibn Uyayna. However, a careful study of the sanad reveals that the above hadith belongs to al-Thawrī because of Khallād b. Yahyā b. Safwān as-Sulamī who never listened to Ibn Uyaynah.

\subsection{Muhammad b. Yūsuf al-Firyābī:}

Abū Abdillāh Muhammad b. Yūsuf al-Firyābī (d. 213/828) listened to the Yūnus b. Abi Ishāq, Mālik b. Mighwal, al-Āwzā̄, Isrāil, Sufyān alThawrī, Sufyān b. Uyaynah, and other prominent Muhaddithūn of his era. Ahmad b. Hanbal (d. 241/855), al-Bukhārī, and al-Dārmī (d. 255/869) are among the students that narrated from him. ${ }^{(11)}$ It may be concluded from the follow up of Muhammad b. Yūsuf's narrations in Sahīh al-Bukhārī that al-Bukhārī narrated approximately seventy-three (73) ahādīth on his sanad that contains the name of al-Thawrī or Ibn Uyaynah. However, a thorough study of all narrations reveal that whenever he narrated from Sufyān al-Thawrī, he refers to him on Sufyān solely as below.

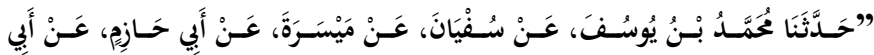

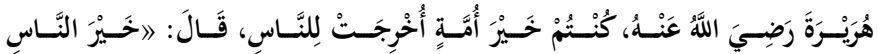

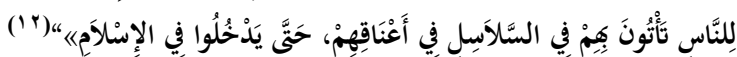

Moreover, whenever he is narrating from Ibn Uyaynah, he identified his source as below.

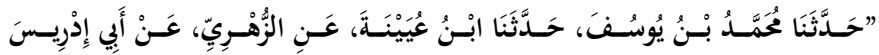

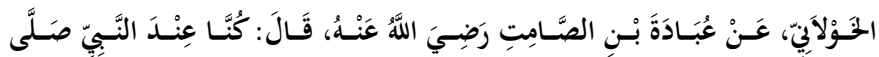

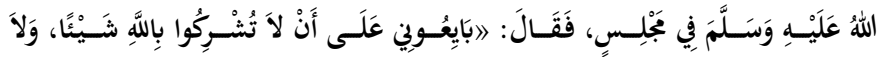

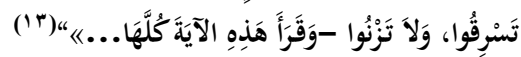

Consequently, a statistical study of Sahīh al-Bukhārī reveals that Muhammad b. Yūsuf al-Firyābī narrated seventy-one (71) ahādīth out of seventy-three (73) ahādīth on the first method while the rest on the second one. It concludes that Muhammad b. Yūsuf al-Firyābī has narrated largely from Sufyān al-Thawrī who is known as al-Mizzī (d. 742/1341). However, Muhammad b. Yūsuf differentiated between his Shuyūkh in all chains. 


\subsection{Sābit b. Muhammad al-Shaibānī:}

Abū Ismāil Sābit b. Muhammad al-Shaibānī (d. 215/830) has narrated ahādīth from Isrāīl b. Yūnus, al-Hārith b. Numān al-Layth̄̄, Husain b. Alī al-Juafī, and Sufyān al-Thawrī. He is one of the prominent Shuyūkh of alBukhārī and Abū Bakr b. Abi Shaībah. (14) However, al-Bukhārī has narrated from him about three (3) ahādith that he narrated from Sufyān alThawrī and he mentioned him as Sufyān only. For instance, he narrated the hadith about someone who strikes his cheeks, rips his garments, and raise noises of Jāhiliyyah from Sufyān. He narrates from Sulaymān alA'mash who is Sheikh of Ibn Uyaynah too with confusion as to whether it is the narration of al-Thawrī or Ibn Uyaynah.

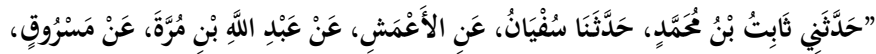

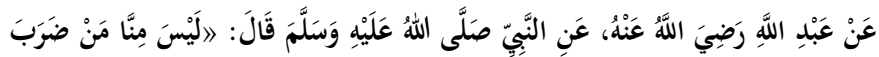

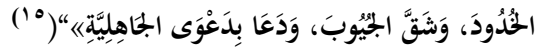

The biographical investigation of the narrators in the above sanad (Chain) determines that the Sufyān in this sanad is Sufyān al-Thawrī because of Sābit b. Muhammad who was a student of al-Thawrī, and he did not have the chance to learn from Ibn Uyaynah.

\subsection{Qabīsa b. Uqba:}

Abū Amir Qabīsa b. Uqba b. Muhammad b. Sufyān (d. 215/830) is the classmate of Sābit b. Muhammad al-Shaybān̄i. Both partake a fair share from the two teachers such as Isrāīl b. Yūnus and Sufyān al-Thawrī. He was the prominent hadith scholar of his time, al-Bukhārī and Ahmad b. Hanbal had narrated from him. (16) Al-Bukhārī has fifty (50) narrations in Sahīh al-Bukhārī that he ascribes to Sufyān. It is noticed that he has narrated about nine ahādīth from Sufyān while his source of narrations is Sulaymān al-A 'mash. The sanad goes like this.

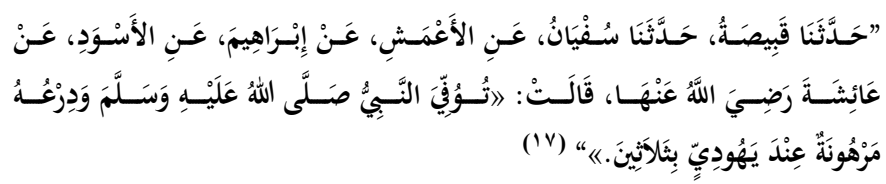

However, all these narrations belong to Sufyan al-Thawrī because Qabīsa Ibn Uqba did not narrate hadith from Ibn Uyaynah.

\subsection{Mālik b. Ismāil:}

Abū Ghassān Mālik b. Ismāil b. Ziyād an-Nahdī (d. 219/834) was a trustworthy Kuffian Muhadith. He had attended lectures of Abū Yūsuf Isrāil al-Hamdān̄̄, Abdullāh b. Abdil-Aziz al-Mājishūn, Sufyān b. Uyaynah, and other philomaths. He was famous among hadith scholars and scrutinizers in his age. Yahyā b Main proclaims that there was not a more reliable narrator in Kūffa than Abū Ghassān. al-Bukhārī, Haroon b. Ishāq al-Hamdān̄̄, Muhammad b. Yahyā az-Zuhlī, Abū Hātim al-Raz̄̄ 
were listed among his students. (18) A careful study of Sahīh al-Bukhārī reveals that al-Bukhārī narrates seven (7) ahādīth from him and that he narrated from Sufyān b. Uyaynah. He conventionally refers to his source on "Ibn Uyaynah," but some times he mentions him as "Sufyān" only. (19)

\subsection{Abū Nu'aim al-Fadl b. Dukayn:}

Abū Nu'aim Amar b. Hamād (d. 219/834) has become famous among hadith scholars on Abū Nu'am al-Fadl b. Dukayn. He had learnt hadith from many cities and had remained a pupil of Sulaymān al-A'mash, Ismāil b. Muslim al-Abd̄̄, Khālid b. Dinār, Sulaymān b. Saif al-Makkī, Sufyān al-Thawrī, Sufyān b. Uyaynah, and many other philomaths. (20) $\mathrm{He}$ is one of those narrators that al-Bukhārī narrates from him extensively. However, he follows the same method of Muhammad b. Yūsuf. He has narrated fifty-six (56) ahādīth from al-Thawrī and refers to him as Sufyān as stated below.

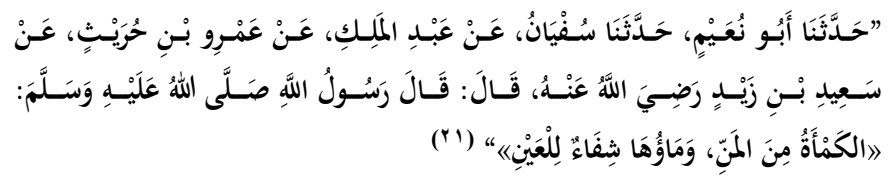

Furthermore, it is noticed that whenever al-Fadl b. Dukayn narrates hadith from Sufyān b. Uyaynah, he mentions his source Ibn Uyaynah without ambiguity. Al-Bukhārī narrates ten (10) ahādīth from him in different subjects referring to his source as "Sufyān b. Uyaynah" as below.

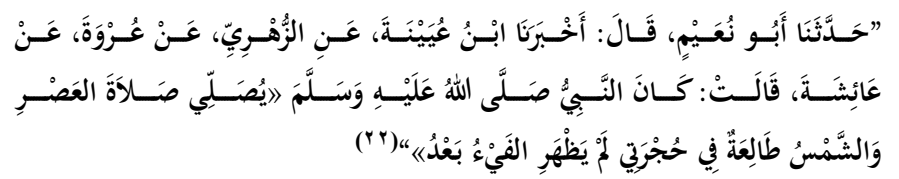

\section{7. al-Humaydī:}

Abdullāh b. al-Zubair b. Isā al-Humaydī al-Makkī (d. 219/834) was a Hijazī Muhadith. He was taught by Ibrāhīm b. Saad, Fudhail b. Ayādh, Sufyān b. Uyaynah, Wakia b. al-Jarrāh and Muhammad b. Idris al-Shāfī̄. He was famous for the narration of Sufyān b. Uyaynah due to his longterm relationship with him. He had a great circle of hadith scholars: alBukhārī, al-Zuhlī, Abū Zura al-Rāzī are listed among his prominent students. (23) Al-Bukhārī narrated from him about seventy-two (72) ahādīth in various subjects which he narrated from Sufyān. ${ }^{(24)}$

A thorough study of his narrations in Sahīh al-Bukhārī reveals that he refers to his source on "Ibn Uyaynah" in one sanad out of seventy-two regarding the meaning of Haddasanā, Akhbrnā, Anbanā, and Samitu. He states that they were synonymous to him. While in the reset, he mentioned his Sheikh Sufyān that is indisputably Ibn Uyayna because he was not taught by al-Thawrī. 


\subsection{Musā b. Mas' 'üd}

Abū Huzaifa Musā b. Mas' '̄ùd an-Nahdī al-Basrī (d. 220/835) narrated ahādīth from several Iraqi and Hijāzī scholars such as Ibrāhīm b. Tahmān, Ibni Nābil al-Makkī, Bahlūl b. Amar al-Kūfī, Sufyān al-Thawrī, and many others. He was also a famous Muhaddith of his time. al-Bukhārī, alDārmī, and Ahmad b. Muhammad al-Marwaz̄ are listed amongst his students. (25) A review of his narration in Sahīh al-Bukhārī reveals that alBukhārī narrates about three (3) ahādīth from him that he ascribes it to Sufyān. However, he narrates a hadith from Sufyān about the Divine Will (al-Qadar), and his Sheikh is Sulaymān al-A 'mash as follows.

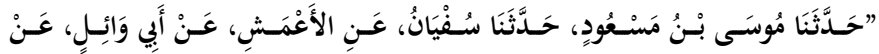

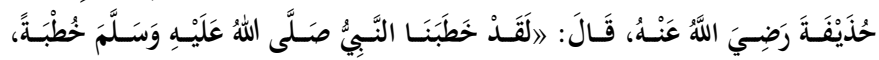

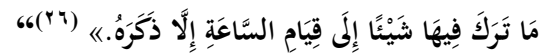

The profound study of the above hadith shows that it is one of the alThawrī narrations because of Musā b. Mas' $\bar{u} d$ who did not receive any teachings from Ibn Uyaynah.

\subsection{Muhammad b. Kathīr al-Abdī:}

Abū Abdillāh Muhammad b. Kathīr al-Abdī al-Basrī (d. 223/838) was the younger brother of the well-kenned Muhaddith Sulaymān b. Kathir. He narrated ahādīth from his brother and Ibrāhīm b. Nafi al-Makkī, Isrāīl b. Yūnus, Shu'ba b. al-Hajjāj, Sufyān al-Thawrī and other Muhaddithūn of his time. Al-Mizzī has listed him in the shuyūkh of al-Bukhārī and Abū Dāwūd. (27) Al-Bukhārī narrates from him about sixty-two (62) ahādīth that he ascribed to his Sheikh Sufyān without referring to his father or tribe. For instance:

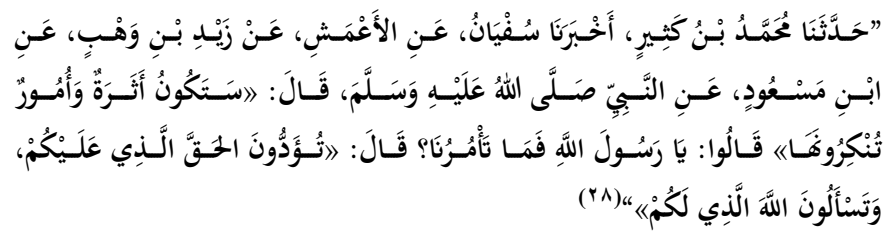

The thought-provoking thing in all his chains is that his Sheikh al-Sheikh is Sulaymān al-A'mash who is the Sheikh of Ibn Uyaynah too however his biography dispelled the confusion that his Sheikh is Sufyān al-Thawrī and all these narrations belong to him.

\subsection{Musaddad:}

Abūl-Hassan Musaddad b. Musarhad (d. 228/842) was one of the famous and prominent hadith scholars throughout Islamic History. He listened to Jawaria bnt. Asmā, Hamād b. Zaid, Abdullāh b. Yahya, Abū Awana, Ibn Uyaynah, Yahyā al-Qatān, and a massive number of other hadith scholars. A thorough review of his biography shows that the well- known compilers of the hadith canonical books such as al-Bukhārī, Abū Dawūd, an-Nisā̄i, and al-Tirmizī were his students. ${ }^{(29)}$

Moreover, an exhaustive study of Sahīh al-Bukhārī reveals that he usually refers to his Sheikh Ibn Uyaynah through Yahyā b. Saīd as below. 


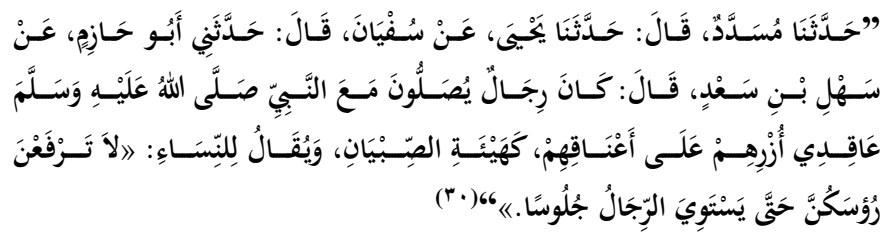

However, in six (6) ahādīth that are narrated in al-Bukhārī in different chapters, refer to him as an authority without an intermediary and mentioned him "Sufyān" who is Sufyān b. Uyaynah ${ }^{(31)}$ because he did not list in the students of al-Thawrī.

\subsection{Abdullāh b. Muhammad:}

Abū Jafar Abdullāh b. Muhammad al-Bukhārī al-Musnadī (d. 229/843) was famous for Musnad. Abū Abdillāh al-Hākim an-Nisabūrī states that he took al-Musnadī as his name because he was the first one who collected the Musnad of the companions on their biographies (al-Trājim) in the Transoxiana (Ma wrā an-Nahar). He listened to Sufyān b. Uyaynah, Fudhail b. Ayādh, Abdu'r-Razzāq al-Sanaān̄̄, and other prominent Muhaddithūn. He had a considerable number of students that served in the field of hadith and its sciences in different regions such as al-Bukhārī, Abū Zura ar-Raz̄i, and Muhammad b. Nasar. (32) Al-Bukhārī narrates thirty-four (34) ahādīth on his authority that he reported from Sufyān. ${ }^{(33)}$

A review of his narrations reveals that he refers to his Sheikh Ibn Uyaynah or Sufyān. However, there are eleven (11) ahādīth that he mentioned his Sheikh Ibn Uyaynah in their Isnāds, ${ }^{(34)}$ though he usually refers to him as "Sufyān."

\subsection{Ali b. Abdillāh al-Madinī:}

Abūl-Hassan Ali b. Abdillāh al-Madin̄i (d. 234/848) is one of the Shuyūkh of al-Bukhārī and a specialist of hadith and its sciences. He took his learning from well-known hadith scholars of his time such as Hamād b. Zaid, Yahyā b. Said al-Qattān, and Sufyān b. Uyaynah. Due to his extraordinary memory, he was famous among the students of hadith. Sufyān b. Uyaynah and Muāz b. Muāz are listed his edifiers but both have the privilege of being taught by him. Muhammad b. Ismāil al-Bukhārī, Abū Dawūd, and Ahmad b. Hanbal recorded ahādīth of him in their compilations. ${ }^{(35)}$

He has about one hundred and eighty (180) narrations from Sufyan b. Uyaynah in Sahīh al-Bukhārī. However, he mentions in one hundred and seventy-nine (179) ahādīth his Sheikh solely Sufyān as below.

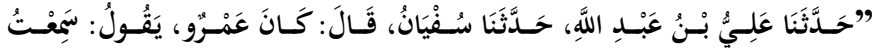

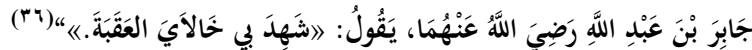

However, the biographical information determines that whenever Ibn alMadin̄̄ mentions his Sheikh Sufyān, it will be Ibn Uyaynah because he never chanced to see al-Thawrī. 


\subsection{Qutaiba b. Saeed:}

Abū Rajā Qutaiba Ibn Said al-Balkh̄̄ al-Baghlan̄̄ (d. 240/854) is a prominent Muahadith and a hadith scrutinizer. He travelled to different cities seeking to learn ahādīth from different Shuyūkh. Therefore he has the privilege of listening from three Tabaqāt. He was present in the lectures of Mālik, al-Layth, Hamād b. Zaid, Sufyān b. Uyaynah, Ibn alMubārak, Fudhail b. Ayādh, Ghundūr, Ibn Wahb, and many other scholars. He is the Sheikh of Ahmad b. Hanbal, al-Bukhārī, al-Tirmizī, an-Nisā̄i, and Ibn Maja. ${ }^{(37)}$ Al-Bukhārī narrates thirty-five (35) ahādith from him that he had narrated from Sufyān b. Uyaynah. In every sanad, he mentions his source Sufyān excepting one. (38) However, these are the narrations of Sufyān b. Uyaynah because he did not listen to al-Thawrī.

\subsection{4. al-Hasan b. Sabāh al-Bazzār:}

Abū Ali al-Hasan b. Sabāh al-Bazzār (d. 249/863) was an Iraqi Muhadith. He narrated from Sufyān b. Uyaynah, Abū Muhammad Ishāq b. Yūsuf alMakhzūmī, Wakia b. al-Jarrāh, Maan b. Isā, Ismāil b. Umar al-Wasit̄̄, and other scholars of his time. ${ }^{(39)}$

Al-Bukhārī, an-Nisāī, Abū Jafar al-Tabarī were listed among his students. Al-Bukhārī cites one narration on his authority that he had learnt from Sufyān Ibn Uyaynah regarding the method of the Prophet in general discussion. However, he referred to his Sheikh in the sanad as "Sufyān" only. ${ }^{(40)}$

\section{Conclusion:}

In concusion we may say that whenever there are two narrators between al-Bukhārī and Sufyān in sanad, it signifies that it is the narration of Sufyān al-Thawrī. Furthermore, if there is one narrator between alBukhārī and Sufyān, it would be the narration of Ibn Uyayna. However, the profound analytical study of five hundred and seventy-eight (578) ahādīth of Sahīh al-Bukhārī reveals that it is not predicated on research because al-Bukhārī narrates multiple times from Khllād b. Yahyā, Sābit b. Muhammad, Muhammad b. Kathīr, and other students of al-Thawrī on one intermediary from Sufyān. On the other hand, there are about thirtythree (33) ahādīth of Musaddad in Sahīh al-Bukhārī who is considered as a student of Ibn Uyaynah whenever he narrates from Sufyān, there are as many as two narrators between al-Bukhārī and Sufyān Ibn Uyaynah.

Subsequently, a careful review of the isnads which bear the name Sufyān only concludes that there are five Shuyūkh of al-Bukhārī who are the students of al-Thawrī and they did not listen to Ibn Uyaynah. Al-Bukhārī narrates one hundred and twenty-five (125) ahādīth on their authority in his compilation. Whenever they are narrating from Sufyān al-Thawrī, they refer to him on "Sufyān" only. They are such as:

1. Khllād b. Yahyā (d. 213/828) mentioned "Sufyān" in seven (7) ahādīth.

2. Sābit b. Muhammad (d. 215/830) referred to al-Thawrī on "Sufyān" in three (3) ahādīth. 
3. Qabīsa b. Uqba (d. 215/830) mentioned his source Sufyān in fifty (50) ahādīth.

4. Musā b. Mas' $\bar{u} \boldsymbol{d}$ (d. 220/835) mentioned Sufyān in three (3) ahādīth.

5. Muhammad b. Kathīr (d. 223/838) mentioned Sufyān in sixty-two (62) ahādīth.

Similarly, there are seven (7) Shuyūkh of al-Bukhārī that are the students of Ibn Uyaynah, and who never took any learning from al-Thawrī. Al-Bukhārī has collected three hundred and twentyfive (325) such ahādīth from them in Sahīh al-Bukhārī. The analytical study of these narrations reveals that whenever they narrate from Ibn Uyaynah, they mention him as Sufyān only. They are as follow:

1. Mālik b. Ismāil (d. 219/834) conventionally referred to his Sheikh as "Ibn Uyaynah," but there is one sanad he mentioned him "Sufyān" only.

2. Al-Humaydī (d. 219/834) mentioned his source Sufyān in seventy-one (71) ahādīth.

3. Abūl-Hasan Musaddad (d. 228/842) referred to Sufyān in six (6) ahādīth.

4. Abdullāh b. Muhammad (d. 229/843) mentioned him in thirtyfour (34) ahādīth.

5. Ali b. Abdillāh al-Madin̄̄ (d. 234/848) referred to Ibn Uyaynah on Sufyān in one hundred and seventy-nine (179) ahādīth.

6. Qutaiba b. Said (d. 240/854) mentioned his source Sufyān in thirty-four (34) ahādīth.

7. al-Hasan b. Sabāh al-Bazzār (d. 249/863) mentioned him in one hadith.

Besides, there are two other narrators in Sahīh al-Bukhārī, who shared Sufyān al-Thawrī and Ibn Uyaynah, and al-Bukhārī narrated one hundred and thirty-nine (139) ahādīth of them that they listened from Sufyān al-Thawrī and Ibn Uyaynah. However, a follow up of their narrations in Sahīh al-Bukhārī reveals the following conclusion.

1. Muhammad b. Yūsuf al-Firyābī (d. 213/828) learnt from both Shuyūkh. Whenever he is narrating from al-Thawrī, he mentions him as Sufyān and about seventy-one (71) ahādīth are quoted from him in Sahīh al-Bukhārī. However, when his source is Ibn Uyaynah, he refers to him as Ibn Uyaynah, even though there are only two narrations in Sahīh al-Bukhārī on this sanad.

2. Abū Nu'aim al-Fadl b. Dukayn (d. 219/834) narrated hadith from Sufyān al-Thawrī and Ibn Uyaynah. He followed the same method of his fellow Muhammad b. Yūsuf al-Firyābī. Consequently, he mentioned his source Sufyān in fifty-six (56) ahādīth that signify Sufyān al-Thawrī and Ibn Uyaynah in ten (10) ahādīth. 
The concise conclusion of the five hundred and seventy-eight (578) ahādīth in Sahīh al-Bukhārī is that the two hundred and fifty-two (252) ahādīth belong to Sufyān al-Thawrī, while three hundred and twenty-six (326) ahādīth belong to Ibn Uyaynah.

\section{(c) This work is licensed under a Creative
Commons Attribution 4.0 International Licence.}

\section{References:}

(1) Ibn Saad, Abū Abdillāh Muhammad b. Saad al-Basrī, al-Tabaqāt al-Kubrā (Complementry Volume), ed. Zyād b. Muhammad (al-Madina: Maktaba al-Ulūm, 1408/1988), 167. Ibn Asākr, Abūl-Qāsam Ali b. Hasan, Tārīkh Dimashq, ed. Amar b. Gharama, (Beirut: Dāru'l-Fikar, 1415/1995), 55: 334. Ibn Abdilbar, Abū Umar Yūsuf b. Abdillāh al-Qurtabī, Jāmi Bayān al-Ilam, ed. Abūl-Ashbāl (al-Saūdia: Dār Ibn alJawzī, 1414/1994), 1: 76.

(2) Ibn Saad, al-Tabaqāt al-Kubrā, 6: 350. al-Mizzī, Yūsuf b. Abdu'r-Rahmān, Tahzib alKamāl, ed. Bshār Awād (Beirut: al-Risāla, 1410/1980), 11: 54.

(3) al-Dhahab̄i, Abū Abdillāh Muhammad b. Ahmad, Siyar a 'ām al-Nubalā', (Beirut: alRisāla, 1405/1985), 7: 234.

(4) al-Dhahabī, Siyar a 'ām al-Nubalā', 7: 237-238.

(5) Ibn Saad, al-Tabaqāt al-Kubrā, 6: 41. al-Khațīb al-Baghdādī, Abū Bakar Ahmad b. Ali, Tārīkh Baghdād, ed. Bashār Awād, (Beirut: Dār al-Gharb, 1422/2002), 10: 244. al-Mizzī, Tahzib al-Kamāl, 11: 178-188.

(6) al-Khațīb al-Baghdādī, Tārīkh Baghdād, 10: 244. al-Dhahabī, Siyar a 'ām al-Nubalā', 8: 456 .

(7) al-Dhahabī, Siyar a 'lām al-Nubalā', 8: 457.

(8) al-Bukhārī, Muhammad b. Ismāil, al-Jāmi 'u's-Sahīh, ed. Muhammad Zuhīr b. Nāsar (Beirut: Dār Tawqu'n-Naja, 1422/2002), “al-Salāt”, 87 (No. 481).

(') al-Mizzī, Tahzib al-Kamāl, 8: 359-361.

(10) al-Bukhārī, "Istibānatu'l-Murtadin", 1 (No. 6921).

( ${ }^{11)}$ al-Mizzī, Tahzib al-Kamāl, 27: 52-60.

(12) al-Bukhārī, "al-Tafsir", 64 (No. 4557).

(13) al-Bukhārī, "al-Hudūd", 9 (No. 6784).

$\left({ }^{14}\right)$ al-Mizzī, Tahzib al-Kamāl, 4: 374-377. 
(15) al-Bukhārī,"al-Manāqib”, 9 (No. 3530) .

(16) al-Mizzī, Tahzib al-Kamāl, 23: 481-490.

(17) al-Bukhārī, "al-Maghāz̄̄”, 88 (No. 4467).

(18) Abū'l-Ḥasan al- 'Ijlì, Ahmad b. Abdillah al-Kūfî. al-Thiqāt, ed. Abdul-Azim (al-Madina: Maktabatu'd-Dār, 1405/1985), 1: 417. Ibn Abī Hātim, al-Jarh wa-l-ta dīl, (India: Dāirtul-Maārif, 1371/1952), 8: 206.

(19) al-Bukhārī, "al-Atq", 17 (No. 2555).

$\left({ }^{20}\right) \quad$ al-Mizzī, Tahzib al-Kamāl, 34: 352.

(21) al-Bukhārī, "al-Azān”, 52 (No. 690). "al-Juma”, 10 (No. 891). "al-Istisqāa”, 16 (No. 1005). “Taqsir al-Salāt”, 5 (No. 1089). “al-Tahagud”, 4 (No. 1124). “al-Janāiz”, 23 (No. 1271). “al-Janāiz", 34 (No. 1294). “al-Haj”, 130 (No. 1732). “al-Haj”, 48 (No. 1765). "al-Buyūa”, 94 (No. 2211). "al-Sulam”, 6 (No. 2253). "al-Wakāla”, 5 (No. 2305). "al-Musaqāt”, 7 (No. 2393). "al-Istiqrāz", 19 (No. 2407). "al-Shurūt", 1 (No. 2714). “al-Wasāya”, 2 (No. 2742). “al-Jihād”, 40 (No. 2846). “al-Jihād”, 19 (No. 3061). “Ahadithu'l-Anbiāa", 34 (No. 3412). "al-Manāqib”, 3 (No. 3504). "al-Manāqib”, 7 (No. 3512). "Manāqib al-Ansār”, 26 (No. 3841). "al-Maghāzī”, 31 (No. 4109). “alMaghāzī”, 46 (No. 4265). “al-Maghāzī”, 54 (No. 4297). “al-Maghāzī”, 69 (No. 4365). “al-Maghāzı̄”, 77 (No. 4392). “al-Tafsir”, 6 (No. 4478). “al-Tafsir”, 41 (No. 4528). "alTafsir”, 222 (No. 4749). “al-Tafsir”, 334 (No. 4918). “al-Tafsir”, 353 (No. 4945). "Fadhāyl al-Qurān”, 1 (No. 4983). "Fadhāyl al-Qurān”, 10 (No. 5009). "Fadhāyl alQurān”, 21 (No. 5028). “Fadhāyl al-Qurān”, 26 (No. 5039). “al-Nikāh”, 81 (No. 5187). “al-Ataima”, 54 (No. 5458). “al-Ashriba”, 16 (No. 5617). “al-Libās”, 14 (No. 5804). "al-Libās", 34 (No. 5847). "al-Adab”, 50 (No. 6056). "al-Adab”, 90 (No. 6146). "alAdab", 96 (No. 6170). "al-Dawāt", 16 (No. 6324). "al-Riqāq", 36 (No. 6499). "alQadar”, 5 (No. 6608). “al-Faraydh”, 21 (No. 6756). “al-diyāt”, 32 (No. 6916). “alHiyal”, 9 (No. 6966). “al-Hiyal”, 14 (No. 6975). "al-Hiyal”, 15 (No. 6980). “alAhkām”, 50 (No. 7216). “al-Itisām”, 2 (No. 7282). “al-Itisām”, 4 (No. 7298). “alItisām”, 16 (No. 7326).

(22) al-Bukhārī, "al-Ghusal", 3 (No. 253). "Mawāqit al-Salāt", 13 (No. 546). "al-Azān", 122 (No. 871). "Taqsir al-Salāt", 17 (No. 1114). "al-Buyūa", 5 (No. 2056). "al- 
Manāqib”, 25 (No. 3597). “al-Adab”, 110 (No. 6200). “al-Istizān”, 49 (No. 6293). “Istitābatu'l-Murtadin”, 4 (No. 6927). “al-Fitan”, 4 (No. 7060).

(23) Ibn Hibān, Muhammad b. Hibānn b. Ahmad, al-Thiqāt, (India: Dāiratu'l-Maārif alUthmānia, 1393/1973), 8: 341. al-Mizzī, Tahzib al-Kamāl, 14: 512.

(24) al-Bukhārī, "Badu'l-Wahȳ̄”, 1 (No. 1). "al-Ilam”, 16 (No. 73). "al-Ghusal”, 8 (No. 260). "al-Salāt”, 30 (No. 395). "al-Janāiz”, 30 (No. 1280). “al-Janāiz”, 36 (No. 1307). “al-Haj”, 41 (No. 1577). “al-Haj”, 80 (No. 1649). “al-Umra”, 11 (No. 1793). “al-Sūm”, 43 (No. 1954). “al-Buyūa”, 47 (No. 2115). “al-Buyūa”, 103 (No. 2223). “al-Atq", 6 (No. 2528). "al-Hiba", 25 (No. 2611). “al-Hiba”, 36 (No. 2636). "al-Jihād”, 28 (No. 2827). "al-Jihād", 119 (No. 2970). “al-Jihād”, 135 (No. 2997). "Fardhu'l-Khums", 4 (No. 3112). "Badu'l-Khalq", 8 (No. 3244). "Badu'l-Khalq", 11 (No. 3278). “Ahadithu'l-Anbiāa", 18 (No. 3377). "Ahadithu'l-Anbiāa", 44 (No. 3445). "Manāqib al-Ansār", 29 (No. 3852). "Manāqib al-Ansār", 37 (No. 3874). "Manāqib al-Ansār", 42 (No. 3888). "Manāqib al-Ansār", 45 (No. 3897). "al-Maghāzī”, 8 (No. 3977). "alMaghāzī”, 58 (No. 4324). “al-Maghāz̄̄”, 58 (No. 4325). “al-Tafsir”, 24 (No. 4498). "al-Tafsir", 2 (No. 4683). "al-Tafsir", 4 (No. 4693). "al-Tafsir”, 3 (No. 4711). "alTafsir”, 11 (No. 4720). “al-Tafsir”, 2 (No. 4725). “al-Tafsir”, 3 (No. 4732). “al-Tafsir”, 1 (No. 4800). "al-Tafsir", 2 (No. 4817). “al-Tafsir", 1 (No. 4826). "al-Tafsir”, 2 (No. 4854). “al-Tafsir”, 5 (No. 4861). "al-Tafsir”, 1 (No. 4890). “al-Tafsir”, 6 (No. 4907). “al-Tafsir", 4 (No. 4915). “al-Tafsir”, 1 (No. 4927). “al-Nikāh”, 26 (No. 5106). “alNafaqāt", 7 (No. 5362). “al-Zabāih”, 27 (No. 5519). “al-Zabāih", 34 (No. 5538). “alAshriba", 14 (No. 5604). "al-Libās", 67 (No. 5899). "al-Libās”, 85 (No. 5941). "alLibās”, 89 (No. 5950). “al-Adab”, 7 (No. 5978). “al-Adab”, 56 (No. 6063). “al-Adab”, 68 (No. 6086). “al-Istizān”, 12 (No. 6243). "al-Dawāt”, 37 (No. 6364). “al-Riqāq", 16 (No. 6448). “al-Riqāq”, 42 (No. 6514). “al-Qadar”, 9 (No. 6613). “al-Aymān Wa’nNuzūr", 15 (No. 6672). “al-Faraydh”, 6 (No. 6733). "al-Itisām”, 1 (No. 7268). “al- 
Itisām”, 15 (No. 7321). “al-Tawhid”, 24 (No. 7445). “al-Tawhid”, 34 (No. 7489). “alTawhid”, 35 (No. 7491). “al-Tawhid”, 41 (No. 7521).

(25) al-Bukhārī, al-Tārīkh al-Kabìr, 7: 295. Abū 1-Ḥasan al- 'Ijlī, al-Thiqāt, 445. al-Dhahabī, Siyar a 'lām al-Nubalā', 10: 137.

(26) al-Bukhārī, “al-Qadar”, 4 (No. 6604).

(27) al-Bukhārī, al-Tārīkh al-Kabīr, 1: 218. Ibn Hibān, al-Thiqāt, 9: 77. al-Mizzī, Tahzib al-Kamāl, 26: 334-336.

(28) al-Bukhārī, “al-Ilam”, 29 (No. 90). “al-Azān”, 135 (No. 814). “al-Juma”, 7 (No. 889). “al-Istisqāa”, 11 (No. 1020). "al-Tahajjud”, 4 (No. 1125). "Fadhlu's-Salāt”, 14 (No. 1215). “al-Janāiz”, 25 (No. 1335). “al-Haj”, 50 (No. 1597). “al-Haj”, 99 (No. 1680). “al-Haj”, 111 (No. 1703). “al-Haj”, 120 (No. 1716). “al-Haj”, 134 (No. 1747). “alBuyūa”, 2 (No. 2051). "al-Buyūa”, 3 (No. 2052). "al-Atq”, 6 (No. 2529). “al-Atq", 16 (No. 2547). "al-Shahādāt", 7 (No. 2647). "al-Shahādāt", 9 (No. 2652). "al-Jihād", 62 (No. 2875). “al-Jihād”, 88 (No. 2916) “al-Jihād”, 154 (No. 3021). “al-Jizya”, 17 (No. 3179). "al-Badu'l-Khalq", 1 (No. 3190). "Ahadithu'l-Anbiāa”, 10 (No. 3349). "alManāqib”, 25 (No. 3603). "al-Manāqib”, 25 (No. 3611). “Ashābu’n-Nab̄̄”, 1 (No. 3651). "Ashābu'n-Nabi”, 5 (No. 3671). "Manāqib al-Ansār", 35 (No. 3863). "Manāqib al-Ansār”, 45 (No. 3913). "al-Maghāz̄̄”, 6 (No. 3959). “al-Maghāzī”, 31 (No. 4113). “al-Maghāzl̄”, 56 (No. 4315). "al-Tafsir”, 14 (No. 4626). “al-Tafsir”, 10 (No. 4667). “al-Tafsir", 4 (No. 4733). “al-Tafsir”, 1 (No. 4774). "al-Tafsir”, 2 (No. 4932). "Fadhāyl al-Qurān”, 8 (No. 5001). "Fadhāyl al-Qurān”, 10 (No. 5008). "Fadhāyl al-Qurān”, 36 (No. 5057). "al-Nikāh, 7 (No. 5072). "al-Talāq", 49 (No. 5345). "al-Nafaqāt”, 1 (No. 5354). "al-Ataima", 1 (No. 5373). "al-Ataima”, 21 (No. 5409). "al-Ashriba”, 10 (No. 5598). “al-Tib”, 35 (No. 5738). “al-Adab”, 3 (No. 5972). “al-Adab”, 15 (No. 5991). “al-Adab”, 20 (No. 6001). "al-Adab”, 39 (No. 6034). “al-Adab”, 61 (No. 6071). "alAdab”, 123 (No. 6221). "al-Istizān”, 39 (No. 6279). "al-Riqāq", 7 (No. 6432). "al- 
Riqāq”, 35 (No. 6497). “al-Hiyal”, 9 (No. 6967). "al-Fitan”, 13 (No. 7086). “alAhkām”, 28 (No. 7180). “al-Itisām”, 16 (No. 7325). “al-Tawhid”, 28 (No. 7458).

al-Bukhārī, al-Tārīkh al-Kabīr, 8: 72. Abū'l-Ḥasan al-'Ijlī, al-Thiqāt, 425. Ibn Abī Hātim, al-Jarh wa-l-ta 'dīl, 8: 438.

(30) al-Bukhārī," "al-Salāt”, 6 (No. 362).

(31) al-Bukhārī, "al-Haj”, 144 (No. 1755). "al-Adhahī”, 3 (No. 5548). "al-Tib”, 12 (No. 5695). “al-Qadar", 12 (No. 6616). “al-Itisām", 2 (No. 7278). “al-Tawhid”, 35 (No. 7503).

(32) Ibn Ab̄̄ Hātim, al-Jarh wa-l-ta 'dīl, 5: 162. Ibn Hibān, al-Thiqāt, 8: 354. al-Dhahab̄̄, Siyar a 'Tām al-Nubalā', 10: 658.

(33) al-Bukhārī, "al-Ilam”, 45 (No. 122). "al-Haydh”, 20 (No. 320). "al-Azān”, 78 (No. 727). “al-Istisqāa”, 18 (No. 1027). “Sujūd al-Qurān”, 5 (No. 1090). “al-Janāiz”, 86 (No. 1371). “Jazāau's-Sayd", 2 (No. 1823). "al-Buyūa", 1 (No. 2050). "al-Musāqāt", 11 (No. 2369). "al-Khasūmāt", 5 (No. 2421). "al-Mukātab", 16 (No. 2597). "al-Shahādāt, 3 (No. 2639). “al-Sulha”, 9 (No. 2704). "al-Jihād”, 76 (No. 2897). “al-Jihād”, 130 (No. 2991). "al-Jihād", 159 (No. 3032). "Manāqib al-Ansār", 8 (No. 3794). "Manāqib alAnsār”, 26 (No. 3848). “al-Maghāzī”, 17 (No. 4044). "al-Maghāzī”, 17 (No. 4046).

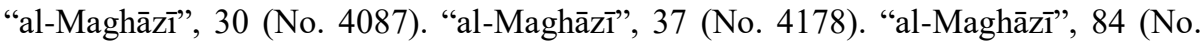
4427). "al-Tafsir", 14 (No. 4587). "al-Ataima”, 27 (No. 5424). "al-Zabāih”, 12 (No. 5494). “al-Ashriba", 8 (No. 5592). “al-Tib”, 10 (No. 5692). “al-Tib”, 57 (No. 5780). “al-Adab”, 106 (No. 6189). “al-Dawāt”, 10 (No. 6317). “al-Tawhid”, 24 (No. 7446).

(34) al-Bukhārī, "al-Buyūa", 2 (No. 2051). "al-Musāqāt”, 18 (No. 2381). "al-Mazālim”, 26 (No. 2467). “al-Qadar”, 7 (No. 6610). “al-Jihād”, 125 (No. 2985). “al-Jihād”, 142 (No. 3008). "al-Tafsir", 24 (No. 4502). "al-Tafsir”, 9 (No. 4664). “al-Tib”, 46 (No. 5761). “al-Tib”, 49 (No. 5765). “al-Tawhid", 31 (No. 7480). al-Bukhārī, al-Tārīkh al-Kabīr, 6: 284. Ibn Abī Hātim, al-Jarh wa-l-ta 'dīl, 1: 319. al-Bukhārī, "al-Ilam”, 15 (No. 72). "al-Ilam”, 40 (No. 113). "al-Wadū”, 5 (No. 138). “al-Wadū", 75 (No. 242). "al-Haydh", 1 (No. 294). "al-Salāt", 18 (No. 377). "al-Salāt", 29 (No. 394). "al-Salāt”, 36 (414). "al-Salāt”, 70 (No. 456). "Mawāqit al-Salāt”, 9 (No. 536). “al-Azān”, 94 (No. 756). “al-Azān”, 127 (No. 805). “al-Azān”, 154 (No. 842). “al-Azān”, 160 (No. 858). “al-Azān”, 160 (No. 859). “al-Juma”, 32 (No. 931). “alIstisqāa”, 4 (No. 1012). "Taqsir al-Salāt”, 13 (No. 1106). "al-Tahajjud”, 1 (No. 1120). "al-Tahajjud”, 7 (No. 1131). "al-Tahajjud”, 22 (No. 1153). “al-Tahajjud”, 27 (No. 1168). “al-Tahajjud”, 30 (No. 1174). “Fadhlu's-Salāt”, 5 (No. 1203). “al-Janāiz”, 33 (No. 1293). “al-Janāiz”, 46 (No. 1307). “al-Janāiz”, 51 (No. 1315). “al-Janāiz”, 77 (No. 
1350). “al-Janāiz”, 79 (No. 1357). “al-Haj”, 20 (No. 1541). “al-Haj”, 47 (No. 1591). “al-Haj”, 80 (No. 1645). “al-Haj”, 80 (No. 1649). “al-Haj”, 85 (No. 1658). “al-Haj”, 92 (No. 1664). “al-Haj”, 143 (No. 1754). “al-Haj”, 147 (No. 1766). “al-Umra”, 6 (No. 1784). “Jazāu's-Sayd”, 2 (No. 1823). “Jazāu's-Sayd”, 10 (No. 1835). "Fadhayl alMadina", 8 (No. 1878). "al-Sūm”, 3 (No. 1895). "al-Sūm”, 33 (No. 1941). “Fadhlu'Laylati'l-Qadar", 1 (No. 2014). "Fadhlu'Laylati'l-Qadar”, 5 (No. 2024). “alItikāf”, 12 (No. 2039). “al-Buyūa”, 35 (No. 2098). "al-Buyūa”, 35 (No. 2099). “alBuyūa”, 49 (No. 2122). "al-Buyūa”, 54 (No. 2135). "al-Buyūa”, 58 (No. 2140). "alBuyūa”, 68 (No. 2157). “al-Buyūa”, 83 (No. 2191). "al-Kafāla, 2 (No. 2297). “alMuzāara”, 9 (No. 2330). “al-Mazālim”, 32 (No. 2476). "al-Mazālim", 69 (No. 2478). "al-Rahan", 3 (No. 2510). "al-Atq", 4 (No. 2521). "al-Hiba", 17 (No. 2598). "alShahādāt", 18 (No. 2665). "al-Shurūt", 17 (No. 2735). "al-Jihād", 1 (No. 2783). "alJihād”, 19 (No. 2815). “al-Jihād", 80 (No. 2904). “al-Jihād”, 96 (No. 2929). “al-Jihād”, 106 (No. 2953). “al-Jihād”, 123 (No. 2980). “al-Jihād”, 141 (No. 3007). “al-Jihād”, 145 (No. 3011). “al-Jihād”, 145 (No. 3012). “al-Jihād”, 149 (No. 3017). "al-Jihād”, 163 (No. 3037). “al-Jihād”, 190 (No. 3074). “al-Jihād”, 194 (No. 3080). "al-Jizia”, 1 (No. 3156). "Badu'l-Khalq", 6 (No. 3212). "Badu'l-Khalq", 7 (No. 3230). "Badu'l-Khalq", 8 (No. 3250). "Badu'l-Khalq”, 58 (No. 3322). “Ahadithu'l-Anbiā", 24 (No. 3397). “Ahadithu'l-Anbiā̄, 27 (No. 3401). "Ahadithu'l-Anbiā", 50 (No. 3460). "Ahadithu'lAnbiā”, 52 (No. 3471). “al-Manāqib”, 1 (No. 3498). “al-Manāqib", 17 (No. 3533). “alManāqib”, 21 (No. 3539). “al-Manāqib”, 25 (No. 3591). “al-Manāqib”, 28 (No. 3642). "al-Manāqib", 28 (No. 3647). "Fadhayal al-Sahāba", 1 (No. 3649). "Manāqib alAnsār", 26 (No. 3833). "Manāqib al-Ansār", 27 (No. 3850). "Manāqib al-Ansār", 35 (No. 3865). "Manāqib al-Ansāro", 43 (No. 3890). "Manāqib al-Ansār", 50 (No. 3939).

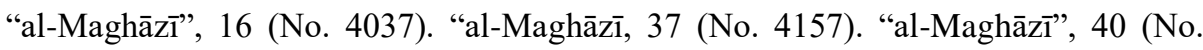
4237). “al-Maghāzī, 45 (No. 4255). “al-Maghāzī”, 58 (No. 4325). “al-Maghāz̄̄”, 67 (No. 4361). “al-Maghāzī”, 84 (No. 4426). “al-Tafsir”, 8 (No. 4558). “al-Tafsir”, 7 (No. 4652). "al-Tafsir”, 3 (No. 4700). "al-Tafsir”, 1 (No. 4701). “al-Tafsir”, 3 (No. 4711). "al-Tafsir", 8 (No. 4716). "al-Tafsir", 1 (No. 4779). “al-Tafsir”, 1 (No. 4865). "alTafsir", 1 (No. 4881). “al-Tafsir”, 3 (No. 4885). “al-Tafsir”, 3 (No. 4894). "al-Tafsir”, 1 (No. 4977). "Fadhāyl al-Qurān", 19 (No. 5024). “al-Nikāh”, 51 (No. 5149). “alNikāh”, 97 (No. 5208). “al-Nikāh”, 112 (No. 5233). “al-Nikāh”, 117 (No. 5238). “alTalāq", 21 (No. 5292). "al-Talāq", 24 (No. 5301). "al-Talāq", 32 (No. 5312). "alTalāq", 50 (No. 5346). "al-Nafaqāt", 10 (No. 5365). "al-Ataima”, 2 (No. 5376). "al- 
Ataima”, 7 (No. 5384). “al-Ataima”, 12 (No. 5395). “al-Ataima”, 52 (No. 5456). "alAqiqa”, 4 (No. 5474). “al-Zabāih", 28 (No. 5529). "al-Adhāh̄̄”, 16 (No. 5567). “alAshriba”, 8 (No. 5593). “al-Ashriba", 24 (No. 5627). “al-Tib”, 21 (No. 5709). “al-Tib”, 21 (No. 5713). “al-Tib", 38 (No. 5745). "al-Libās", 15 (No. 5806). "al-Libās", 91 (No. 5954). “al-Adab”, 43 (No. 6042). “al-Adab”, 55 (No. 6062). “al-Adab”, 97 (No. 6173). “al-Adab”, 106 (No. 6188). “al-Adab”, 114 (No. 6206). "al-Istizān”, 9 (No. 6237). “alIstizān”, 11 (No. 6241). “al-Istizān", 13 (No. 6245). “al-Istizān”, 42 (No. 6284). “alIstizān”, 44 (No. 6287). "al-Istizān", 53 (No. 6303). "al-Dawāt”, 19 (No. 6333). “alDawāt", 28 (No. 6347). "al-Dawāt", 65 (No. 6402). "al-Dawāt", 12 (No. 6410). "alRiqāq", 11 (No. 6441). "al-Qadar", 10 (No. 6614). "Kafārātu'l-Imān”, 2 (No. 6709). “Kafārātu'l-Imān", 10 (No. 6720). "al-Hudūd”, 30 (No. 6827). "al-Hudūd”, 30 (No. 6829). "al-Hudūd", 44 (No. 6854). "al-Hudūd”, 44 (No. 6855). "al-Diyāt”, 23 (No. 6902). “al-Hiyal”, 4 (No. 6969). “al-Hiyal”, 14 (No. 6977). “al-Tabir”, 45 (No. 7042). “al-Fitan", 7 (No. 7073). “al-Fitan", 21 (No. 7109). “al-Fitan”, 21 (No. 7110). “alAhkām”, 18 (No. 7165). “al-Ahkām”, 24 (No. 7174). “al-Taman̄̄”, 9 (No. 7238). “Akhbār al-Ahād”, 2 (No. 7261). “al-Itisām”, 2 (No. 7276). “al-Itisām”, 8 (No. 7309). “al-Itisām”, 11 (No. 7313). “al-Tawhid”, 32 (No. 7481). “al-Itisām”, 45 (No. 7529). al-Bukhārī, al-Tārīkh al-Kabīr, 7: 195. Ibn Abī Hātim, al-Jarh wa-l-ta 'dīl, 7: 140. Ibn Hibānn, al-Thiqāt, 9: 20. al-Dhahabī, Siyar a 'lām al-Nubalā', 11: 13.

(38) al-Bukhārī, "al-Salāt", 66 (No. 451). "al-Salāt”, 92 (No. 752). "al-Istiqāa”, 17 (No. 1026). “al-Haj”, 69 (No. 1623). “al-Buyūa", 110 (No. 2231). "al-Sulam”, 2 (No. 2241). "alWakāla", 12 (No. 2313). "al-Sulha”, 4 (No. 2694). "al-Wasāyā", 3 (No. 2743). "alJihād", 140 (No. 3006). "al-Jihād", 158 (No. 3031). "Fardhu'l-Khums", 4 (No. 3111). "Badu'l-Khalq", 10 (No. 3266). "Ahādithu'l-Anbiāa”, 38 (No. 3420). "al-Manāqib”, 25 (No. 3594). "Manāqib al-Ansār", 34 (No. 3862). "al-Maghāzī”, 18 (No. 4052). "alMaghāzī”, 47 (No. 4274). “al-Maghāzì”, 75 (No. 4383). “al-Maghāzì”, 85 (No. 4431). "al-Tafsir", 5 (No. 4840). "al-Tafsir", 1 (No. 4976). "Fadhāyl al-Qurān”, 16 (No. 5019). “al-Nikāh”, 63 (No. 5161). "al-Nikāh", 124 (No. 5248). "al-Talāq", 52 (No. 5350). “alAdhāhī”, 10 (No. 5559). "al-Adab”, 68 (No. 6086). "al-Adab”, 82 (No. 6131). “alRiqāq", 45 (No. 6525). “al-Farāydh”, 1 (No. 6723). "al-Farāydh", 31 (No. 6771). “alDiyāat", 8 (No. 6881). "al-Tawhid", 34 (No. 7489).

(39) al-Bukhārī, al-Tārīkh al-Kabīr, 2: 295. Ibn Abī Hātim, al-Jarh wa-l-ta 'd̄̄l, 3: 19. Ibn Hibān, al-Thiqāt, 8: 176. al-Mizzī, Tahzib al-Kamāl, 6: 191-195. 